\title{
PD-1 Antibody Combined With Decitabine Is Effective in the Treatment of Refractory Peripheral T-cell Lymphoma Not Otherwise Specified: a Case Report
}

xiao han

Army Medical University Second Affiliated Hospital: Xinqiao Hospital https://orcid.org/0000-0002-4361-872X

Qin Wen ( $\sim$ qiqi105@sina.com )

Army Medical University Second Affiliated Hospital: Xinqiao Hospital https://orcid.org/0000-0001-7388-6285

Xue Liu

Army Medical University Second Affiliated Hospital: Xinqiao Hospital

Kai Wan

Army Medical University Second Affiliated Hospital: Xinqiao Hospital

Hongju Yan

Army Medical University Second Affiliated Hospital: Xinqiao Hospital

Cheng Zhang

Army Medical University Second Affiliated Hospital: Xinqiao Hospital

Xi Zhang

Army Medical University Second Affiliated Hospital: Xinqiao Hospital

Research Article

Keywords: Peripheral T-cell lymphoma, not otherwise specified (PTCL-NOS), PD-1 antibody, Decitabine

Posted Date: May 4th, 2021

DOI: https://doi.org/10.21203/rs.3.rs-455987/v1

License: (c) (i) This work is licensed under a Creative Commons Attribution 4.0 International License. Read Full License 


\section{Abstract}

Background: Peripheral T-cell lymphoma not otherwise specified (PTCL-NOS) is a highly aggressive lymphoma with a poor response to chemotherapy, frequent relapses, low overall survival, and poor prognosis, and is the most common form of PTCL. For relapsed/refractory (R/R) PTCLs, the efficacy of traditional chemotherapy is even worse, so clinical trials and new drugs become their therapeutic hopes. Here, We report on a 43-year woman with refractory PTCL-NOS has a good response to PD-1 antibody combined with decitabine.

Case presentation: A 43-year-old woman with refractory PTCL-NOS, who has a poor efficacy in the first-line and second-line treatments, even the disease progresses after treatment with histone deacetylase inhibitors and proteasome inhibitors, however, has a good response to PD-1 antibody combined with decitabine. The patient got significant tumor regression and some of the masses even disappeared.

Conclusions: The PD-1 monoclonal antibody combined with decitabine may be a good choice to improve prognosis when used early if conventional first- and second-line regimens, histone deacetylase inhibitors, and proteasome inhibitors are ineffective.

\section{Background}

Peripheral T-cell lymphoma, not otherwise specified (PTCL-NOS) is a group of highly heterogeneous and aggressive malignant tumors[1], accounting for approximately $30-50 \%$ of PTCLs[2], usually occurring in middle-aged and elderly patients, with a male-to-female ratio of 1.5-1.9:1.0[3]. PTCL-NOS is characterized by systemic diseases with nodal or extranodal involvement, including lymph nodes, skin, liver, spleen, bone marrow, and peripheral blood. Nearly half of cases may have B symptoms at diagnosis, and may also encounter hemophagocytic syndrome characterized by fever, cytopenia, and spleen/liver enlargement[4]. There is no standard treatment regimen established for PTCL-NOS currently. The response to conventional chemotherapy is rather poor, and the 5-year median overall survival (OS) rate is usually less than $30 \%[5]$. Besides, PTCL-NOS has no clear phenotype. Currently, the World Health Organization (WHO) classification of PTCL-NOS is based on its morphologic, immunophenotypic, cytogenetic and clinical features[6, 7]. In summary, no standard therapeutic regimens for PTCL-NOS were reported in previous studies, and there is a long way to go before we can conquer this hard nut. Here, we report a case of refractory PTCL-NOS, which has a poor efficacy in the first-line and second-line treatments, and even suffers disease progression with the treatment of histone deacetylase inhibitors and proteasome inhibitors. However, with the combined treatment of PD- 1 antibody and decitabine, the patient got significant tumor regression and some of the masses even disappeared. Unfortunately, this patient developed IV degree of myelosuppression during remission and finally died of respiratory failure. In review of the previous studies of PTCL-NOS, we found that there existed no reports of such therapeutic strategy is effective in this disease. Therefore, we report this case for dissucssion and potential reference.

\section{Case Presentation}

A 43-year-old Chinese female inadvertently found multiple breast masses in April 2018, the larger one was about $2 \mathrm{~cm} * 3 \mathrm{~cm}$, self-conscious hard, clear border, good mobility, tenderness, no fever, itching, redness, etc. On June 6, 2018, she visited Chongqing Cancer Hospital \& Chongqing University Cancer Hospital and a puncture biopsy of a right breast mass was performed. On June 21, the tissue examination revealed peripheral T-cell lymphoma, not otherwise specified (PTCL-NOS), and immunohistochemistry showed CD45 + Bcl-6 scattered + Bcl-2 scattered + CD 5 + MUM-1 individual + Cyclin D1 + CD99dim + Fli- $1+$ Ki67 + > 80\%, CD13- CD15- CD33- CD68(kp1)- CD68(PG-M1)- CD117- CD56- MPO- TdT- CK- Syn- CgA- Desmin- Myogenin- MyoD1- CK7- CD3- CD20- CD21- CD10- CD23EBER-positive control + NSE-. On June 27th 18-F-fluorodeoxyglucose (FDG) positron emission tomography (PET) revealed that an abnormal FDG accumulation in bilateral neck, clavicular region, axillary fossa, upper limb, mediastinum, double hilar, abdominal wall, retroperitoneum, intestinal space, pelvic cavity, bilateral inguinal multiple lymphadenopathy, double lung, bilateral breast, stomach wall, left adrenal gland, spleen, occipital, under the chest wall multiple masses, and the whole body bone with high metabolic activity (SUVmax: 4.75-23.4), considering lymphoma involvement. On June 29, the first course of chemotherapy was started with P-CHOP (Pegaspargase 3750iu, epirubicin 80mg, cyclophosphamide 1.2g, vindesine 4mg, prednisone 500mg) and intrathecal injection, which cerebrospinal fluid was normal. On July 16th, the second course of HD-MTX(5g)and intrathecal injection were given. After a few days the masses reduced in size. On August 8th, the third course of treatment was given to P-CHOP and intrathecal injection. On August 23, the fourth course of HD-MTX $\nabla 5 \mathrm{~g} \otimes$ was given and intrathecal injection. However, in the chemotherapy period, the masses increased again, and the disease progression (PD) was evaluated.

On September 5,2018 , the left breast mass biopsy was performed again and the pathological presentation showed thar left breast mass conformed to peripheral T cell lymphoma with T-follicular helper cell phenotype, and immunohistochemistry were CD $3+\mathrm{CD} 20-\mathrm{CD} 21-\mathrm{ki}-67+80 \% \mathrm{Bcl}-2+\mathrm{CD} 2 \mathrm{p}+\mathrm{CD} 5+\mathrm{CD} 7$ + CD 4 + CD 8 + CD56- GranzymB focal area + TIA-1 focal area + Perforin- TdT- PD-1 + CXCL-13- CD10- Bcl-6 + CD30- MUM- 1 scattered in + Cyclin D1 + 10\% Sox11- CD23- CD117- CD33- CK- LCA+; Simultaneously, gastroscopy and biopsy showing pathological findings that stomach body conformed to peripheral Tcell lymphoma, NOS, and immunohistochemistry showed tumor cells CD3 + + CD20- CD21- Bcl-2 + Ki-67 (about 30\%+) CD10- Bcl - 6 + MUM-1 (scattered in small amount+) CD5 ++ CD23- CyclinD1 (scattered in small amount+) SOX11 (small stove+) CD30- c-myc (about 70\%) TdT- PAX-5- p53 (about 20\%) CD43++ $\mathrm{K}$ chain (small stove + ) $\lambda$ chain- CD4 ++ CD8 ++ CD56- CD2 + CD7p+, EBER in situ hybridization-. On September 8 and October 1 , respectively, the 5th and 6th courses of the GDP regimen (gemcitabine $1.65 \mathrm{~g} \star 2 \mathrm{~d}$, cisplatin $120 \mathrm{mg} \star 2 \mathrm{~d}$, and dexamethasone $40 \mathrm{mg} \star 4 \mathrm{~d}$ ) were combined with histone deacetylase inhibitors Chidamide. On October 30 , the assessment again considered the progress of the disease (PD).

She admitted our hospital on November 7, 2018. Specialist examination: chronic illness, anemia, obvious pigmentation of the whole body, a large amount of scattered dandruff, superficial lymph nodes (submandibular, neck, armpit, trochle, groin, armpit) reaching the enlarged lymph nodes, which the texture is tough, fixed, obvious pain of inguinal lymph nodes. Both hearing weaked, the double breast touched multiple masses, with no tenderness, toughness, clear borders, good mobility, and mild edema in both lower limbs. Bone marrow cytology showed that bone marrow hyperplasia was active and lymphocyte morphology was abnormal, considering Non-Hodgkin's lymphoma bone marrow image and iron deficiency anemia (NHL-BMI, IDA). Skin biopsy pathology showed that pre-neck 
V-zone skin consistent with peripheral T-cell lymphoma, tumor cell CD20- CD2 + CD3 + CD4 + CD5 + CD7 + CD8 + CD30- GranB- Ki-67 approximately 10\% TCR recombinant+. As a result, combined with the patient history and examination, the diagnosis of refractory PTCL was established. So on November 9th and December 3rd, two courses of DEAD (doxorubicin liposome $20 \mathrm{mg} \star 3 \mathrm{~d}$, etoposide $150 \mathrm{mg} \star 3 \mathrm{~d}$, cytarabine $500 \mathrm{mg} \star 3 \mathrm{~d}$, dexamethasone $15 \mathrm{mg} \star 5 \mathrm{~d}$ ) were combined with Chidamide, which consciously the masses shrinked after chemotherapy, but the interval increased again. On December 18, the CLAG program (Cladribine $10 \mathrm{mg} \star 5 \mathrm{~d}$, cytarabine $1 \mathrm{~g} \star 4 \mathrm{~d}, \mathrm{G}-\mathrm{CSF} 150 \mathrm{ug} \star 3 \mathrm{~d}$ ) was combined with thalidomide, and Simultaneously, the second generation gene sequencing showed: Notch 1 and SOCS1 mutations.

At the beginning of January 2019, the patient's skin lesions, facial and limb edema were aggravated, and the finger joints were seen in the masses (Fig. 1), which the disease progression (PD) was evaluated. On January 14th, the PD regimen (bortezomib 2.27mg d1, 4, 8, 11 and dexamethasone 20mg d1-4, 8-11) was given, and edema slightly relieved on the 2nd day of treatment. But on January 18th, the whole body began ro appear a large number of scattered masses, with highlighting the leather surface, hard, no tenderness, and progressively enlarging, which the largest one is located in the lower abdomen, about $3 \mathrm{~cm} * 5 \mathrm{~cm}$ (Fig. 2), and the whole body appeared edema again. Therefore, we added bcl-2 inhibitors - venetoclax, and the disease still progressed after the end of the treatment.

On January 29th we tried PD-1 antibody - Carellidizumab (SHR-1210, 200mg, every 3 weeks) (Suzhou Shengdia Biomedical Co., Ltd.) combined with decitabine (25mg*5d). After treatment, the body masses was significantly reduced (Fig. 3), some of the masses disappeared, edema subsided, and evaluation of partial remission (PR). Unfortunately, before receiving the second cycle, the patient developed IV ${ }^{\circ}$ myelosuppression and severe pulmonary infection. Despite the step up of antibiotic therapy and the addition of corticosteroids, the patient worsened, and eventually died of respiratory failure (Table 1).

Table 1

Treatment timescales

\begin{tabular}{|c|c|c|c|c|}
\hline & Start time & therapy & $\begin{array}{l}\text { Number of } \\
\text { cycles }\end{array}$ & effect \\
\hline \multirow[t]{4}{*}{1 st } & 2018/6/29, & P-CHOP (Pegaspargase, Epirubicin, Cyclophosphamide, Vindesine, Prednisone) & 4 & Stable disease; \\
\hline & 2018/7/16, & HD-MTX & & Progressive \\
\hline & 2018/8/8, & $\mathrm{P}-\mathrm{CHOP}$ & & \\
\hline & $2018 / 8 / 23$ & HD-MTX & & \\
\hline \multirow[t]{2}{*}{ 2nd } & 2018/9/8, & GDP (Gemcitabine, Cisplatin, Dexamethasone) + Chidamide(20mg, po, twice a week) & 2 & Progressive \\
\hline & 2018/10/1 & & & uisease \\
\hline \multirow[t]{2}{*}{$3 r d$} & 2018/11/9, & DEAD (Doxorubicin liposome, Etoposide, Cytarabine, Dexamethasone ) + Chidamide(20mg, & 2 & Progressive \\
\hline & $2018 / 12 / 3$ & & & uisedse \\
\hline 4th & $2018 / 12 / 18$ & CLAG (Cladribine, Cytarabine ) + Thalidomide(25mg, po., daily) & 1 & $\begin{array}{l}\text { Progressive } \\
\text { disease }\end{array}$ \\
\hline 5th & 2019/1/14 & PD (Bortezomib, Dexamethasone) + Venetoclax & 1 & $\begin{array}{l}\text { Progressive } \\
\text { disease }\end{array}$ \\
\hline 6th & $2019 / 1 / 29$ & Carellidizumab (200mg iv. every 3 weeks) + Decitabine (25mg iv. d2-6) & 1 & Partial response \\
\hline
\end{tabular}

\section{Discussion}

PTCL-NOS, a most common subgroup of PTCL, includes cases that do not correspond to any of the defined entities[8]. About $35 \%-45 \%$ of cases were diagnosed with B symptoms, including fever, systemic lymphadenopathy, fatigue, and unexplained weight loss. Sometimes, pruritus, eosinophilia, and hemophagocytic syndrome may be characteristic of this disease $[9,10]$. Extranodal lesions can occur in approximately half of the cases, with the skin and gastrointestinal tract being the most frequently affected extranodal sites. Four prognostic index have been published to estimate survival in patients with PTCL-NOS, including age, serum LDH levels, performance status (PS), bone marrow involvement, Ann Arbor stage, extranodal involvement, thrombocytopenia, and tumor Ki-67 index[11, 12]. In addition, EBV and CCR4 positive are also poor prognostic factors[13, 14]. This patient had an ECOG score of 1 point, elevated $\mathrm{LDH}$, bone marrow involvement, skin and gastrointestinal involvement, and EBV positive.

The best treatment options for PTCL-NOS are still controversial, due to its heterogeneity, complex clinical manifestations, difficult diagnosis, and lack of randomized controlled studies. The first-line chemotherapy regimen recommended by NCCN 2016 is CHOP, EPOCH, and Hyper-CVAD/MTX-Ara-C, and secondline options include DHAP, ESHAP, GDP, GND, GemOx, ICE, GVD, and new drugs such as pralatrexate, alemtuzumab, bortezomib, diltiazem, bendamustine, histone deacetylase inhibitor, PD-1/PDL-1 antibody, CD30 antibody - brentuximab vedotin, etc[15], or combined with chemotherapy[5]. Data on R/R PTCL will be presented separately, when available (Table 2). The patient's previous first-line and second-line treatment regimen was ineffective, even treated with the histone deacetylase inhibitor - Chidamide, the disease still progresses, which confirmed the diagnosis of relapsed/refractory PTCL-NOS, with stage IVb. In review with the patient's medical history and previous treatment regimens, different combinations of doxorubicin liposome, cladribine, bortezomib, thalidomide, etc. were had successively given, and the masses were progressively increased, which considering the treatment is ineffective. Even with new treatment regimens, relapsed/refractory PTCL-NOS patients still have poor survival outcomes, so there is an urgent need to develop more effective treatments for these patients[16, 17]. The US Food and Drug Administration (FDA) has approved brentuximab vedotin (BV) in 2011 for the treatment of relapsed PTCL patients with CD30 postive $[5,18]$. Because of the patient's multiple biopsy immunohistochemistry showing CD30 negative, so BV was not considered. 
Table 2

Selected Clinical Trial in Relapsed or Refractory PTCL patients, including PTCL-NOS

\begin{tabular}{|c|c|c|c|c|c|c|c|c|c|c|}
\hline Treatment & $\begin{array}{l}\text { Trial } \\
\text { Phase }\end{array}$ & $\begin{array}{l}\text { No. of } \\
\text { patients }\end{array}$ & $\begin{array}{l}\text { No. of } \\
\text { PTCL-NOS }\end{array}$ & ORR & CR & $\begin{array}{l}\text { Median } \\
\text { PFS }\end{array}$ & Median OS & Toxicity & $\begin{array}{l}\text { ClinicalTrials. } \\
\text { gov Identifier }\end{array}$ & Reference \\
\hline $\begin{array}{l}\text { Romidepsin, } \\
\text { Liposomal } \\
\text { Doxorubicin }\end{array}$ & 1 & 12 & $5(42 \%)$ & $27 \%$ & $27 \%$ & 2.1 mouths & $\begin{array}{l}17.5 \\
\text { months }\end{array}$ & $\begin{array}{l}\text { grade } 3 / 4 \\
\text { treatment-related } \\
\text { hematologic AEs }\end{array}$ & $\mathrm{N} / \mathrm{A}$ & 33 \\
\hline Darinaparsin & I & 14 & $10(71.4 \%)$ & $28.6 \%$ & $7.1 \%$ & N/A & N/A & $\begin{array}{l}\text { hematologic } \\
\text { toxicities, } \\
\text { nonhematologic } \\
\text { toxicities (nausea, } \\
\text { hepatic } \\
\text { dysfunction and } \\
\text { prolonged aPTT) }\end{array}$ & N/A & 34 \\
\hline $\begin{array}{l}\text { Bendamustine, } \\
\text { Carboplatin, } \\
\text { Dexamethasone }\end{array}$ & II & 28 & N/A & $54 \%$ & $29 \%$ & 4.4 mouths & N/A & $\begin{array}{l}\text { grade } 3 \text { or } 4 \\
\text { neutropenia, } \\
\text { thrombocytopenia, } \\
\text { and anemia }\end{array}$ & NCT02424045 & 35 \\
\hline Pralatrexate & N/A & 71 & N/A & $52 \%$ & N/A & 4.8months & 18months & $\begin{array}{l}\text { stomatitis, anemia } \\
\text { and alanine } \\
\text { aminotransferase } \\
\text { increase }\end{array}$ & NCT03349333 & 36 \\
\hline Alisertib & III & 138 & $62(45 \%)$ & $33 \%$ & $18 \%$ & 115days & 14 months & $\begin{array}{l}\text { anemia and } \\
\text { neutropenia }\end{array}$ & NCT01482962 & 37 \\
\hline $\begin{array}{l}\text { Romidepsin, } \\
\text { Ifosfamide, } \\
\text { Carboplatin, } \\
\text { Etoposide }\end{array}$ & I & 18 & $7(39 \%)$ & $93 \%$ & $80 \%$ & 10 months & 15 months & $\begin{array}{l}\text { thrombocytopenia, } \\
\text { anemia, } \\
\text { neutropenia, } \\
\text { fatigue, } \\
\text { nausea/vomiting, } \\
\text { infections, } \\
\text { dyspnea and } \\
\text { transaminitis }\end{array}$ & NCT01590732 & 38 \\
\hline Pralatrexate & $\mathrm{I} / \mathrm{II}$ & 25 & $12(48 \%)$ & $45 \%$ & $10 \%$ & 150days & not reached & $\begin{array}{l}\text { mucositis, } \\
\text { thrombocytopenia, } \\
\text { liver function test } \\
\text { abnormality, } \\
\text { anemia and } \\
\text { lymphopenia }\end{array}$ & NCT02013362 & 39 \\
\hline Romidepsin & $\mathrm{N} / \mathrm{A}$ & 130 & $69(53.1 \%)$ & $24 \%$ & $13 \%$ & 5.4months & 18.2months & thrombocytopenia & NCT00426764 & 40 \\
\hline Mogamulizumab & II & 35 & $15(42.86 \%)$ & $11.4 \%$ & $2.86 \%$ & 2.1months & not reached & $\begin{array}{l}\text { drug eruption, } \\
\text { pyrexia, diarrhea, } \\
\text { and pruritus }\end{array}$ & N/A & 41 \\
\hline $\begin{array}{l}\text { Gemcitabine, } \\
\text { Romidepsin }\end{array}$ & II & 20 & $10(50 \%)$ & $30 \%$ & $15 \%$ & 2.5 months & 18 months & $\begin{array}{l}\text { thrombocytopenia, } \\
\text { neutropenia, and } \\
\text { anemia }\end{array}$ & NCT01822886 & 42 \\
\hline $\begin{array}{l}\text { Panobinostat, } \\
\text { Bortezomib }\end{array}$ & II & 23 & N/A & $43 \%$ & $21.5 \%$ & N/A & N/A & $\begin{array}{l}\text { thrombocytopenia, } \\
\text { neutropenia, } \\
\text { diarrhoea, and } \\
\text { asthenia or } \\
\text { fatigue }\end{array}$ & NCT00901147 & 43 \\
\hline Chidamide & II & 79 & $27(34 \%)$ & $28 \%$ & $14 \%$ & 2.1months & $\begin{array}{l}21.4 \\
\text { months }\end{array}$ & $\begin{array}{l}\text { thrombocytopenia, } \\
\text { leucopenia and } \\
\text { neutropenia }\end{array}$ & N/A & 44 \\
\hline Belinostat & II & 120 & $77(64.2 \%)$ & $25.8 \%$ & $10.8 \%$ & 1.6months & 7.9 months & $\begin{array}{l}\text { anemia, } \\
\text { thrombocytopenia, } \\
\text { dyspnea, and } \\
\text { neutropenia }\end{array}$ & N/A & 45 \\
\hline Alisertib & II & 37 & $13(35 \%)$ & $30 \%$ & $7 \%$ & 3 months & 8 months & $\begin{array}{l}\text { neutropenia, } \\
\text { anemia, } \\
\text { thrombocytopenia, } \\
\text { febrile } \\
\text { neutropenia, } \\
\text { mucositis, and } \\
\text { rash }\end{array}$ & NCT01466881 & 46 \\
\hline
\end{tabular}

In recent years, blocking immune checkpoints is considered an important breakthrough in cancer treatment, especially PD-1 inhibitors in anti-tumor therapy. The anti-PD-1 monoclonal antibody specifically binds to the PD-1 molecule on the surface of T cells, thereby blocking the PD-1/Programmed Cell Death-1 (PDL1) pathway, which leading to tumor immune tolerance, re-activating the anti-tumor activity of lymphocytes, thereby achieving the purpose of treating tumors[19]. As far as lymphoma is concerned, PD-1 antibody has a significant effect on classic Hodgkin's lymphoma[20]. Kwong et al. reported the results of PD-1 antibody - Pembrolizumab in the treatment of R/R ENKTL patients who failed asparaginase therapy, showing that the overall response rate (ORR) was 
$100 \%$ (7/7), and the CR rate was 71.4\% (5/7)[21]. Barta SK,et al. have shown that PD-1 monoclonal antibody - Pembrolizumab exhibits modest single-agent activity in relapsed or refractory T-cell lymphoma, mainly through AKT inhibition of T-cell receptor-mediated signal transduction[22]. Several studies have also confirmed the presence of abnormally hypermethylation in T-cell lymphoma and their cell lines, often occurring in the promoter region of tumor suppressor genes (eg:P15INK4B, SHP-1, P53) and leading to silencing of the gene.

Recently, recurrent mutations in epigenetic modified genes have been found in PTCL-NOS. Importantly, studies by Ji MM, et al. provide clinical evidence that histone-modified gene mutations, particularly those involved in histone methylation and acetylation, which is significantly associated with tumor chemoresistance and disease progression in PTCL-NOS[23]. Decitabine is a nucleoside analogue. Phosphatiated decitabine is involved in DNA synthesis, and then covalently binds to DNA methyltransferase to inhibit its activity, resulting in hypomethylation of DNA and activation of tumor suppressor genes, thereby which cause cell differentiation or apoptosis $[24,25]$.

It has been reported that DNA methylation of new organisms promotes T cell failure and limits anti-PD-1 immunotherapy, while methylation inhibition can enhance T cell regeneration mediated by PD-1 blockade[26, 27]. Theoretically, decitabine and anti-PD-1 antibodies play a synergistic effect to restore immune surveillance. Nevertheless, in a small retrospective analysis, a high CR rate of PD-1 inhibitors was observed in several patients with relapsed/refractory cHL who had received epigenetic therapy[28]. Whether the combination of anti-PD-1 antibody and decitabine can enhance the anti-tumor T cell lymphoma effects has not been reported. Combined with the review of relevant literature, this patient still chooses decitabine combined with carrelizumab for treatment, and the effect is also definite. The results had shown that the combination of decitabine and carrelizumab is safe, and the CR rate for patients with relapsed/refractory $\mathrm{CHL}$ is very high[29]. Since immune-based therapy requires appropriate immune activation, the epigenetic modifier decitabine can promote $\mathrm{T}$ cell activation and enhance the effectiveness and duration of the clinical response of anti-PD-1 antibodies.

The patient was found to be positive for PD-1 in immunohistochemistry, so we tried PD-1 antibody combined with decitabine. After treatment, the whole body mass was significantly reduced, and some of the masses disappeared, which was considered effective. By destroying the combination of PD-1 and PD-L1 on tumors or other immunosuppressive cells, PD-1 blockers can restore the activity of tired T cells. However, compared with effector and memory $\mathrm{T}$ cells, exhausted T cells have unique epigenetic properties and will not be remodeled by PD-1 blockade, which may limit the long-lasting anti-tumor ability of anti-PD1 antibodies[30]. Low-dose decitabine may change the epigenetic status of tumors and immune cells. Although decitabine alone is not sufficient to treat advanced solid tumors, low-dose decitabine can enhance T cell activity, promote the infiltration of CD $8+$ and CD $4+T$ cells, increase the sensitivity of chemotherapy drugs and broaden the T cell receptor library in peripheral blood[31, 32]. Therefore, the enhanced anti-tumor response of decitabine combined with PD-1 blockers may be caused by multiple mechanisms. Although this patient's disease has been effectively relieved, we expect allogeneic hematopoietic stem cell transplantation after better control of the disease. Unfortunately, due to multiple strong chemotherapy, the patient developed IV degree of myelosuppression during the course of the disease and eventually died of respiratory failure.

\section{Conclusion}

In summary, this case report on the diagnosis of relapsed/refractory PTCL-NOS is rare. Survival outcomes in patients with progressed/relapsed PTCL-NOS were still poor, with no significant changes even with new treatment regimens. It is necessary to enter the clinical trial at an early stage and combinated the new drugs, which after the disease is controlled, allogeneic hematopoietic stem cell transplantation can be performed as soon as possible to improve survival. Reviewing the course of the patient, PD-1 monoclonal antibody combined with decitabine may be a good choice and improve prognosis with early using when conventional first- and second-line regimens, histone deacetylase inhibitors, and proteasome inhibitors et al. are ineffective. Further research is necessary to evaluate this novel treatment option.

\section{Abbreviations}

FDG: fluorodeoxyglucose; FDG-PET: 18-F-fluorodeoxyglucose-positron emission tomography; HD-MTX: high dose of methotrexate; IDA: iron-deficiency anemia; NHL-BMI: non-hodgkin's lymphoma bone marrow image; PTCL-NOS: peripheral T-cell lymphoma, not otherwise specified; OS: overall survival; PD: disease progression; PS: performance status; PD-1/ PD-L1: programmed cell death protein 1 and its ligand; BV: brentuximab vedotin.

\section{Declarations}

\section{Acknowledgements}

Not applicable

\section{Authors' contributions}

HX drafted the manuscript. WQ administered chemotherapy. LX, WK, YHJ are involved in the medical treatment and took care of the patient's follow-up. ZC provided academic advice. ZX contributed to manuscript revision. All authors read and approved the final manuscript.

\section{Funding}

Supported by grants from the National Natural Science Fund (No. 81873424), Science and technology innovation leading talent program of Chongqing (cstccxljrc201718), the technique innovation and applied program of Chongqing (cstc2019jscx-msxmX0147), Outstanding young talents project of AMU (2017R005).

\section{Availability of data and materials}


All data generated or analyzed are included in this published article

\section{Ethics approval and consent to participate}

All data were collected anonymously and with patient's consent. All procedures in this study were approved by the Ethics Committee of the Second Affiliated Hospital of Army Medical University.

\section{Consent for publication}

Written informed consent was obtained from the patient for the publication of this case report and any accompanying images.

\section{Competing interests}

The authors declare that they have no competing interests.

\section{References}

1. Weisenburger DD, Savage KJ, Harris NL, Gascoyne RD, Jaffe ES, MacLennan KA, et al. Peripheral T-cell lymphoma, not otherwise specified: a report of 340 cases from the International Peripheral T-cell Lymphoma Project. Blood. 2011;117:3402-3408.

2. Iqbal J, Wilcox R, Naushad H, Rohr J, Heavican TB, Wang C, et al. Genomic signatures in T-cell lymphoma: How can these improve precision in diagnosis and inform prognosis? Blood Rev. 2016;30:89-100.

3. Al-Zahrani M, Savage KJ. Peripheral T-cell lymphoma, not otherwise specified: a review of current disease understanding and therapeutic approaches. Hematol Oncol Clin North Am. 2017; 31:189-207.

4. Foss FM, Zinzani PL, Vose JM, Gascoyne RD, Rosen ST, Tobinai K. Peripheral T-cell lymphoma. Blood. 2011;117:6756-6767.

5. Broccoli A, Zinzani PL. Peripheral T-cell lymphoma, not otherwise specified. Blood. 2017; 129:1103-1112.

6. Sabattini E, Bacci F, Sagramoso C, Pileri SA. WHO classification of tumours of haematopoietic and lymphoid tissues in 2008: an overview. Pathologica. 2010; 102:83-87.

7. Swerdlow SH, Campo E, Pileri SA, Harris NL, Stein H, Siebert R, et al. The 2016 revision of the World Health Organization classification of lymphoid neoplasms. Blood. 2016; 127:2375-2390.

8. Lakshmanan A, Sikri D, Patil S, Kurian A, Annapurneswari S, Nair S. Frequency, distribution, and immunomorphologic characteristics of peripheral T-cell lymphoma, not otherwise specified in a tertiary care center in Southern India. Indian J Pathol Microbiol. 2018; 61:204-208.

9. Chan JK. Splenic involvement by peripheral T-cell and NK-cell neoplasms. Semin Diagn Pathol. 2003; 20:105-120.

10. Jani A, Innes M, Reddy V, Prieto-Granada CN, Graham LV, Ergen EN. Peripheral T-cell lymphoma, not otherwise specified, presenting with generalized ulcerated plaques and hypereosinophilia. JAAD Case Rep. 2018; 4:651-654.

11. Xu P, Yu D, Wang L, Shen Y, Shen Z, Zhao W. Analysis of prognostic factors and comparison of prognostic scores in peripheral T cell lymphoma, not otherwise specified: a single-institution study of 105 Chinese patients. Ann Hematol. 2015; 94:239-247.

12. Gallamini A, Stelitano C, Calvi R, Bellei M, Mattei D, Vitolo U, et al. Peripheral T-cell lymphoma unspecified (PTCL-U): a new prognostic model from a retrospective multicentric clinical study. Blood. 2004; 103:2474-2479.

13. Asano N, Suzuki R, Ohshima K, Kagami Y, Ishida F, Yoshino T, et al., Linkage of expression of chemokine receptors (CXCR3 and CCR4) and cytotoxic molecules in peripheral T cell lymphoma, not otherwise specified and ALK-negative anaplastic large cell lymphoma. Int J Hematol. 2010; 91:426-435.

14. Chen Y, Zheng X, Chen B, Yang X, Zheng J, Zheng Z, et al. The clinical significance of Epstein-Barr virus DNA in peripheral blood mononuclear cells in patients with non-Hodgkin lymphoma. Leuk Lymphoma. 2017; 58:2349-2355.

15. Horwitz SM, Zelenetz AD, Gordon LI, Wierda WG, Abramson JS, Advani RH, et al. NCCN guidelines insights: non-Hodgkin's lymphomas, version 3.2016. J Natl Compr Canc Netw. 2016; 14:1067-1079.

16. Oluwasanjo A, Kartan S, Johnson W, Alpdogan O, Gru A, Mishra A, et al. Peripheral T-Cell Lymphoma, not Otherwise Specified (PTCL-NOS). Cancer Treat Res. 2019;176:83-98.

17. Schmitz N, de Leval L. How I manage peripheral T-cell lymphoma, not otherwise specified and angioimmunoblastic T-cell lymphoma: current practice and a glimpse into the future. Br J Haematol. 2017; 176:851-866.

18. Chihara D, Fanale MA, Miranda RN, Noorani M, Westin JR, Nastoupil LJ, et al. The survival outcome of patients with relapsed/refractory peripheral T-cell lymphoma-not otherwise specified and angioimmunoblastic T-cell lymphoma. Br J Haematol. 2017; 176:750-758.

19. Patel SP, Kurzrock R. PD-L1 expression as a predictive biomarker in cancer immunotherapy. Mol Cancer Ther. 2015; 14:847-856.

20. Ansell SM, Lesokhin AM, Borrello I, Halwani A, Scott EC, Gutierrez M, et al. PD-1 blockade with nivolumab in relapsed or refractory Hodgkin's lymphoma. N Engl J Med. 2015; 372(14):311-319.

21. Kwong YL, Chan T, Tan D, Kim SJ, Poon LM, Mow B, et al. PD1 blockade with pembrolizumab is highly effective in relapsed or refractory NK/T-cell lymphoma failing 1-asparaginase. Blood. 2017; 129(17):2437-2442.

22. Barta SK, Zain J, MacFarlane AW 4th, Smith SM, Ruan J, Fung HC, et al. Phase II Study of the PD-1 Inhibitor Pembrolizumab for the Treatment of Relapsed or Refractory Mature T-cell Lymphoma. Clin Lymphoma Myeloma Leuk. 2019 3. pii: S2152-2650(18)31750-6.

23. Ji MM, Huang YH, Huang JY, Wang ZF, Fu D, Liu H, et al. Histone modifier gene mutations in peripheral T-cell lymphoma not otherwise specified. Haematologica. 2018; 103:679-687. 
24. Gilbert J, Gore SD, Herman JG, Carducci MA. The clinical application of targeting cancer through histone acetylation and hypomethylation. Clin Cancer Res. 2004; 10:4589-4596.

25. Cowan LA, Talwar S, Yang AS. Will DNA methylation inhibitors work in solid tumors? A review of the clinical experience with azacitidine and decitabine in solid tumors. Epigenomics. 2010; 2:71-86.

26. Ghoneim HE, Fan Y, Moustaki A, Abdelsamed HA, Dash P, Dogra P, et al. De novo epigenetic programs inhibit PD-1 blockade-mediated T cell rejuvenation. Cell. 2017; 170(1):142-157.

27. Pauken KE, Sammons MA, Odorizzi PM, Manne S, Godec J, Khan O, et al. Epigenetic stability of exhausted T cells limits durability of reinvigoration by PD1 blockade. Science. 2016; 354(6316): 1160-1165.

28. Falchi L, Sawas A, Deng C, Amengual JE, Colbourn DS, Lichtenstein EA, et al. High rate of complete responses to immune checkpoint inhibitors in patients with relapsed or refractory Hodgkin lymphoma previously exposed to epigenetic therapy. J Hematol Oncol. 2016; 9(1):132.

29. Nie J, Wang C, Liu Y, Yang Q, Mei Q, Dong L, et al. Addition of Low-Dose Decitabine to Anti-PD-1 Antibody Camrelizumab in Relapsed/Refractory Classical Hodgkin Lymphoma. J Clin Oncol. 2019; 37(17):1479-1489.

30. Sen DR, Kaminski J, Barnitz RA, Kurachi M, Gerdemann U, Yates KB, et al. The epigenetic landscape of T cell exhaustion. Science. 2016; 354(6316):11651169.

31. Nie J, Zhang Y, Li X, Chen M, Liu C, Han W. DNA demethylating agent decitabine broadens the peripheral T cell receptor repertoire. Oncotarget. 2016; 7(25):37882-37892.

32. Li X, Zhang Y, Chen M, Mei Q, Liu Y, Feng K, et al. Increased IFNy+ T cells are responsible for the clinical responses of low-dose DNA-demethylating agent decitabine antitumor therapy. Clin Cancer Res. 2017; 23(20):6031-6043.

33. Vu K, Wu CH, Yang CY, Zhan A, Cavallone E, Berry W, et al. Romidepsin Plus Liposomal Doxorubicin Is Safe and Effective in Patients with Relapsed or Refractory T-Cell Lymphoma: Results of a Phase I Dose-Escalation Study[J]. Clin Cancer Res. 2020;26(5):1000-1008.

34. Ogura M, Kim WS, Uchida T, Uike N, Suehiro Y, Ishizawa K, et al. Phase I studies of darinaparsin in patients with relapsed or refractory peripheral T-cell lymphoma: a pooled analysis of two phase I studies conducted in Japan and Korea[J]. Jpn J Clin Oncol. 2021;51(2):218-227.

35. Park BB, Kim WS, Suh C, Hong JY, Yang DH, Lee WS, et al. A phase II trial of bendamustine, carboplatin, and dexamethasone for refractory or relapsed peripheral T-cell lymphoma (BENCART trial)[J]. Leuk Lymphoma. 2019 Dec;60(13):3251-3257.

36. Hong XN , Song YQ, Huang HQ , Bai B, Zhang HL, Ke XY, et al. Pralatrexate in Chinese Patients with Relapsed or Refractory Peripheral T-cell Lymphoma: A Single-arm, Multicenter Study[J]. Target Oncol. 2019 Apr;14(2):149-158.

37. O'Connor OA, Özcan M, Jacobsen ED, Roncero JM, Trotman J, Demeter J, et al. Randomized Phase III Study of Alisertib or Investigator's Choice (Selected Single Agent) in Patients With Relapsed or Refractory Peripheral T-Cell Lymphoma[J]. J Clin Oncol. 2019 Mar 10;37(8):613-623.

38. Strati P, Chihara D, Oki Y, Fayad LE, Fowler N, Nastoupil L, et al. A phase I study of romidepsin and ifosfamide, carboplatin, etoposide for the treatment of patients with relapsed or refractory peripheral T-cell lymphoma[J]. Haematologica. 2018 Sep; 103(9): e416-e418.

39. Maruyama D, Nagai H, Maeda Y, Nakane T, Shimoyama T, Nakazato T, et al. Phase I/II study of pralatrexate in Japanese patients with relapsed or refractory peripheral T-cell lymphoma[J]. Cancer Sci. 2017 Oct;108(10):2061-2068.

40. Foss F, Pro B, Prince HM, Sokol L, Caballero D, Horwitz S, Coiffier B. Responses to romidepsin by line of therapy in patients with relapsed or refractory peripheral T-cell lymphoma[J]. Cancer Med. 2017 Jan;6(1):36-44.

41. Zinzani PL, Karlin L, Radford J, Caballero D, Fields P, Chamuleau MED, et al. European phase II study of mogamulizumab, an anti-CCR4 monoclonal antibody, in relapsed/refractory peripheral T-cell lymphoma[J]. Haematologica. 2016 Oct;101(10):e407-e410.

42. Pellegrini C, Dodero A, Chiappella A, Monaco F, Degl'Innocenti D, Salvi F, et al. A phase II study on the role of gemcitabine plus romidepsin (GEMRO regimen) in the treatment of relapsed/refractory peripheral T-cell lymphoma patients[J]. J Hematol Oncol. 2016 Apr 12;9:38.

43. Tan D, Phipps C, Hwang WYK, Tan SY, Yeap CH, Chan YH, et al. Panobinostat in combination with bortezomib in patients with relapsed or refractory peripheral T-cell lymphoma: an open-label, multicentre phase 2 trial[J]. Lancet Haematol. 2015 Aug;2(8):e326-e333.

44. Shi Y, Dong M, Hong X, Zhang W, Feng J, Zhu J, et al. Results from a multicenter, open-label, pivotal phase II study of chidamide in relapsed or refractory peripheral T-cell lymphoma[J]. Ann Oncol. 2015 Aug;26(8):1766-1771.

45. O'Connor OA, Horwitz S, Masszi T, Hoof AV, Brown P, Doorduijn J, et al. Belinostat in Patients With Relapsed or Refractory Peripheral T-Cell Lymphoma: Results of the Pivotal Phase II BELIEF (CLN-19) Study[J]. J Clin Oncol. 2015 Aug 10;33(23):2492-2499.

46. Barr PM, Li HI , Spier C, Mahadevan D, LeBlanc M, Haq MUl, et al. Phase II Intergroup Trial of Alisertib in Relapsed and Refractory Peripheral T-Cell Lymphoma and Transformed Mycosis Fungoides: SWOG 1108[J]. J Clin Oncol. 2015 Jul 20;33(21):2399-2404.

\section{Figures}




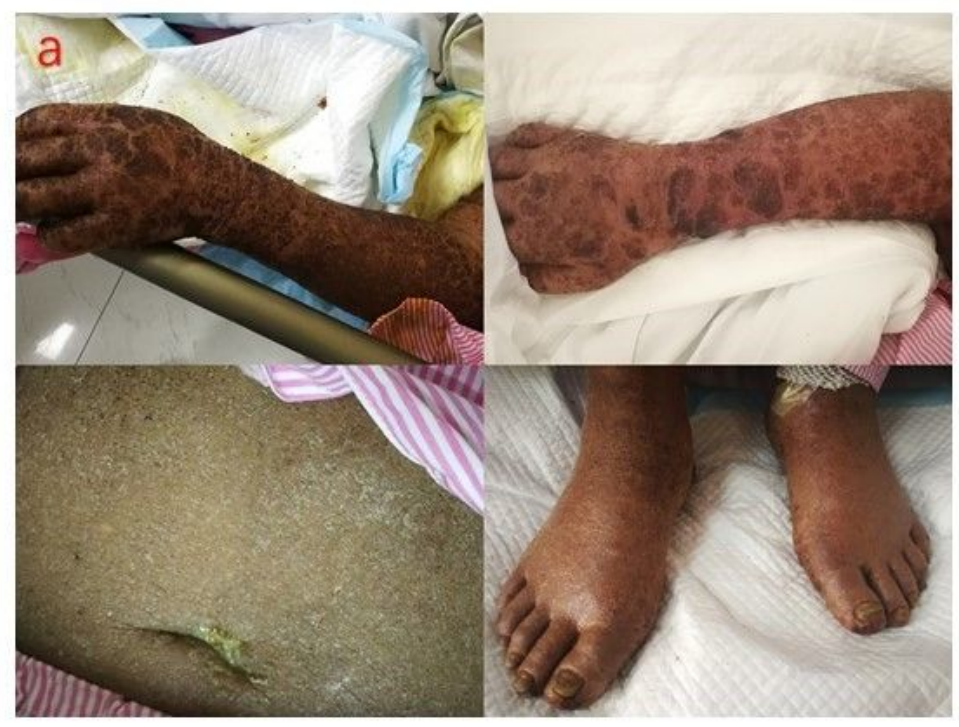

Figure 1

skin lesions, facial and limb edema, and the finger joints were seen in the masses.

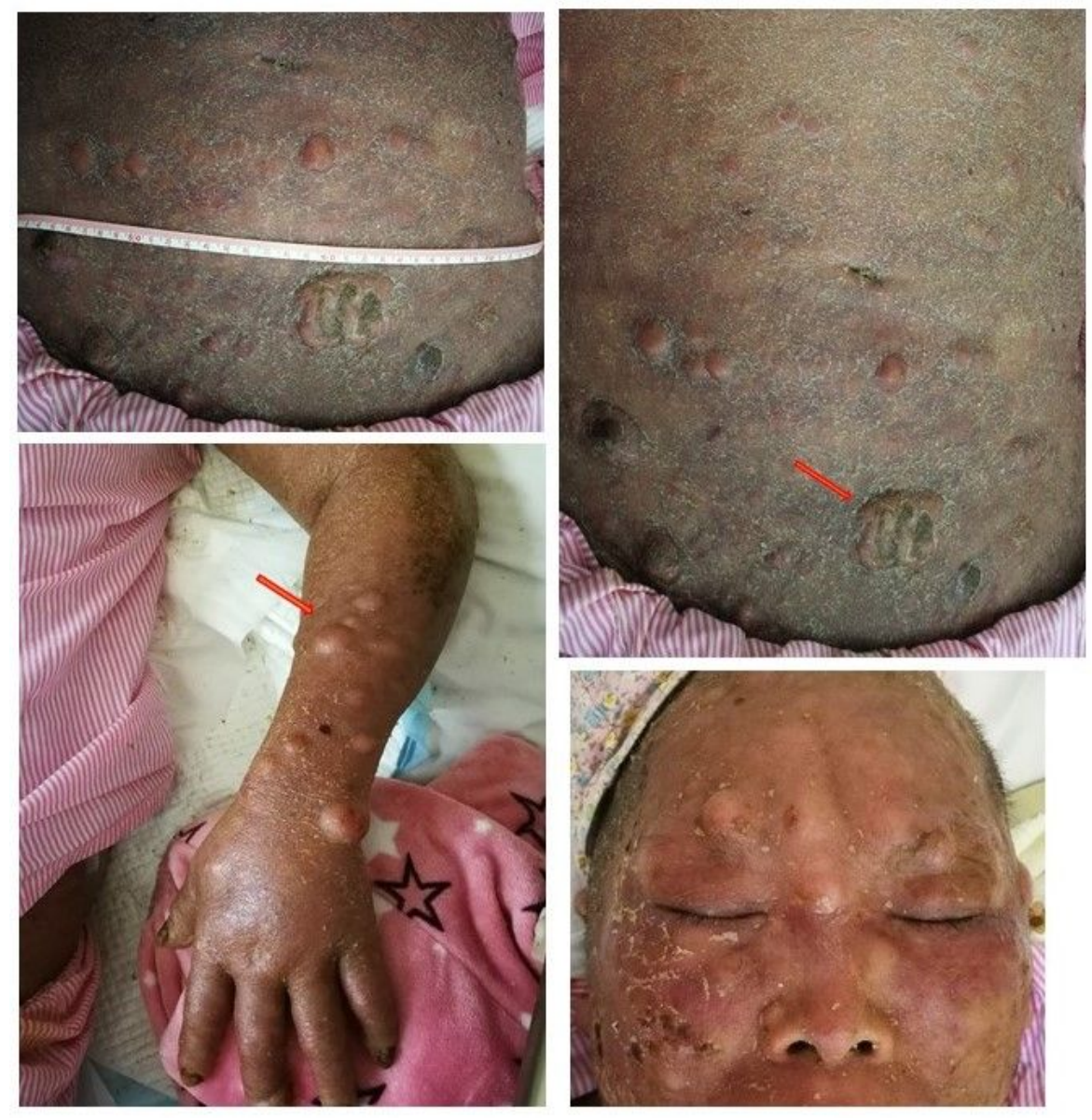

\section{Figure 2}

PTCL-NOS involvement in skin causing skin masses seen on the limbs, face, and abdomen, etc. PTCL-NOS: peripheral T cell lymphoma, not otherwise specified. 

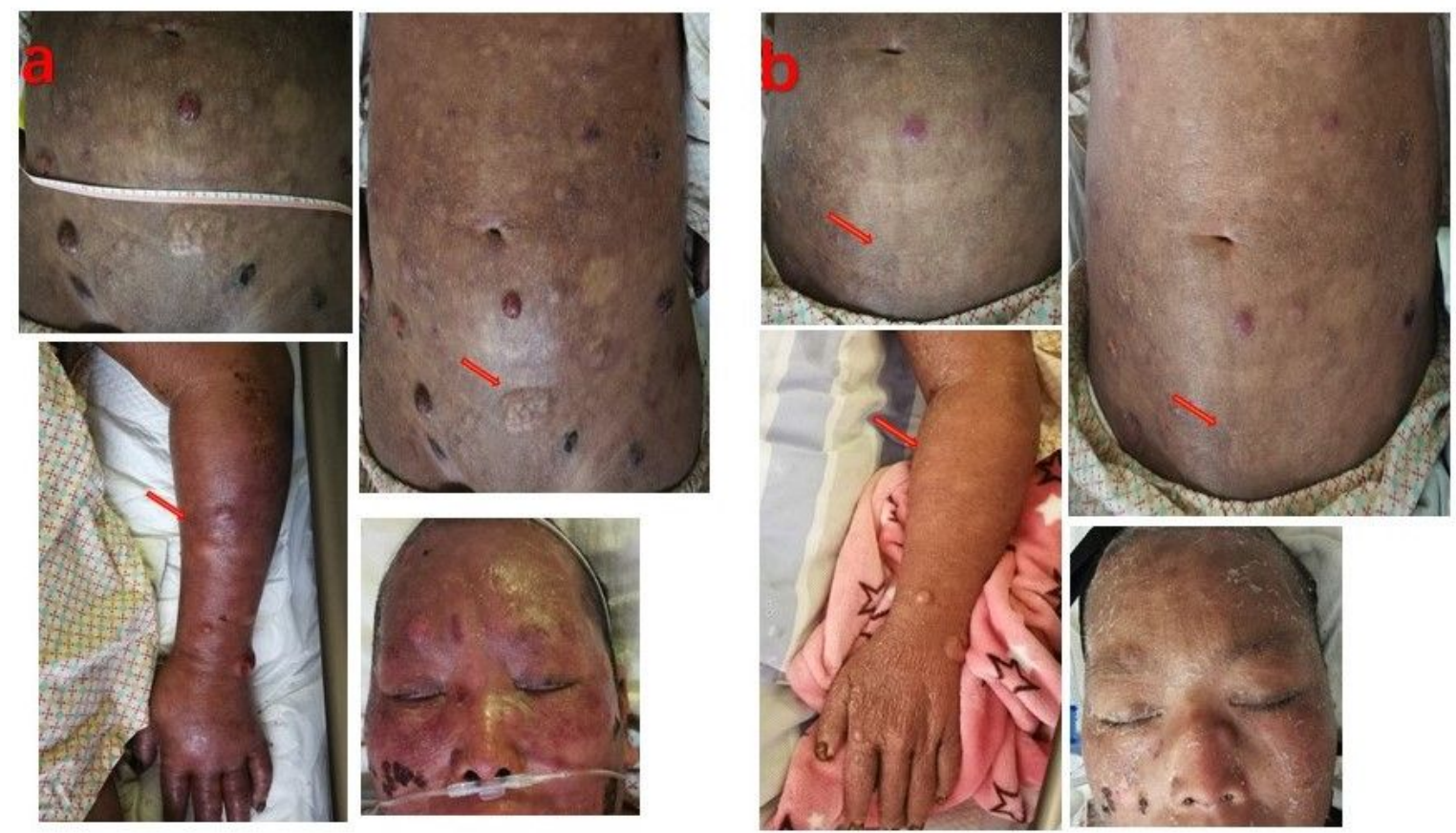

\section{Figure 3}

skin of the limbs, face, and abdomen masses were significantly reduced, and some of the masses disappeared. a, on the 4th day after PD-1 mAb combined with decitabine treatment. $b$, on the 16th day after PD-1 mAb combined with decitabine treatment. 